Agro-Science Journal of Tropical Agriculture, Food, Environment and Extension

Volume 11 Number 1 Januarv 2012 nn 33 - 36

ISSN 1119-7455

\title{
DISTRIBUTION OF PHOSPHORUS ALONG A TOPOSEQUENCE ON AN ALFISOL IN MINNA, NIGER STATE.
}

\author{
Tsado $^{1}$, P. A., Igwe' ${ }^{2}$,C. A., Lawal ${ }^{1}$ B. A. S.,Ezenwa ${ }^{1}$, M. I.,Adeboye ${ }^{1}$ M.K.A.,and Eze ${ }^{1}$ P. C. \\ ${ }^{1}$ Department of Soil Science, Federal University of Technology, P.M.B 65, Minna, Niger \\ State. \\ ${ }^{2}$ Department of Soil Science, University of Nigeria, Nsukka, Enugu State. \\ *Corresponding author email: tsadophilips@yahoo.com
}

\begin{abstract}
The distribution of various forms of phosphorus was evaluated along a toposequence located in an Alfisol in Teaching and Research Farm of the Federal University of Technology, Minna. The toposequence was delineated into different topographic units (Crest, Upper slope, Middle slope and Lower slope). Soil samples were collected from identified horizons in profile pits in each topographic unit. The soil samples were analyzed for organic, total, available and various active $P$ forms. The results obtained showed that distribution of phosphorus varied widely with each topographic unit.

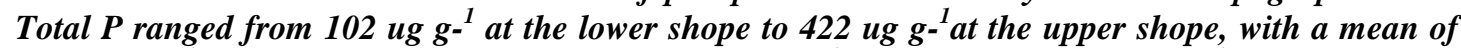

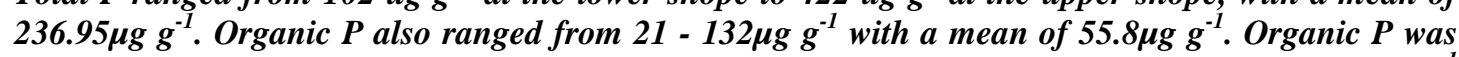
highest at the lower slope and lowest at the upper slope. Available P ranged from $0.4-5.54 \mu \mathrm{g} g^{-1}$ with a mean of $2.47 \mu \mathrm{g}^{-1}$. The active $\mathrm{P}$ forms was in the order of $\mathrm{Fe}-\mathrm{P}>\mathrm{Al}-\mathrm{P}>\mathrm{Ca}-\mathrm{P}$, with $\mathrm{Fe}-\mathrm{P}$ varying from $19-95 \mu \mathrm{g} \mathrm{g}^{-1}, \mathrm{Al}-\mathrm{P}$ ranged from $1.75-22 \mu \mathrm{g} \mathrm{g}^{-1}$ and $\mathrm{Ca}-\mathrm{P}$ ranged from 1.12- $4.3 \mu \mathrm{g}$ $g^{-1}$. There was a positive correlation between organic $P$ and clay $\left(r=0.56^{*}\right)$ and between organic $P$ and organic carbon $(r=0.52 *)$. However, organic $P$ correlated negatively with sand $(r=-0.49 *)$.Fe $P$ and $A l-P$ correlated with magnesium $\left(r=0.51^{*}\right)$ and sand $\left(r=0.45^{*}\right)$ respectively. Available $P$ also correlated positively with clay $(r=0.43 *)$ and organic carbon $(r=0.52 *)$.
\end{abstract}

Key words: Toposequence, Alfisol, Crest, Active P and Organic P.

\section{INTRODUCTION}

Phosphorus (P) is an important nutrient element classified as a macro-nutrient because of its relatively large amount required by plants. Phosphorus plays key roles in many plant processes such as energy metabolisms, synthesis of nucleic acids and membrane, photosynthesis, respiration, nitrogen fixation and enzyme regulation. Phosphorus occurs in various forms in the soil as organic and inorganic. The inorganic $\mathrm{P}$ in soil is further classified as iron bound phosphate, aluminium bound phosphate and calcium phosphate (Jianbo et al, 2011).

Phosphorus has been identified as one of the most limiting nutrient elements in tropical soils (Ahn, 1993). This low availability of phosphorus in tropical soils is attributed to the nature and forms of the soil phosphorus and the high contents of the oxides of iron and aluminium, which are associated with phosphate fixation (Osodeke and Osondu, 2006).

According to Juo and Moorma (1981), toposequence refers to a succession of sites from the crest to the valley bottom, which contains a range of soil profiles that are representatives of the landscape and soil. Distribution of individual soil series on a toposequences as well as the spatial distribution of the toposequence itself has considerable influence on the soil properties and land use pattern (Ogban, et al, 1999). Oluwatosin et al. (2001) therefore recommended that agronomic practices be adopted after due consideration of specific topographic locations which might influence mineral availability and fertilizer recommendation.

Since Nigerian soils are highly weathered with low in $\mathrm{P}$ status, information about $\mathrm{P}$ characteristics is necessary for the 
management of $\mathrm{P}$ fertility of Nigerian soils. However, no dealed study on the distribution of $\mathrm{P}$ along a toposequence has been conducted. This study was therefore conducted to provide more information on the distribution of phosphorus along a toposequence in an Alfisol in southern guinea savanna zone of Nigeria.

\section{MATERIALS AND METHODS}

This study was carried out in Teaching and Research Farm of the Federal University of Technology, Minna (Latitude $9^{0} \quad 4^{10} \mathrm{~N}$ and Longitude $\left.6^{0} \quad 3^{10} \mathrm{E}\right)$. The toposequence was delineated into crest, upper slope, middle slope and lower slope. Soil samples were collected from identified horizons in profile pits in each of the topographic units. The samples collected from the identified horizons were air dried, crushed and sieved through a $2 \mathrm{~mm}$ sieve. A small portion of the sample was further ground and sieved with $0.5 \mathrm{~mm}$ mesh sieve and used for total $\mathrm{P}$, organic $\mathrm{P}$ and organic carbon determination.

Particle size distribution was determined by the hydrometer method after dispersion with sodium hexametaphosphate according to the procedure described by I.I.T.A (1976). The soil $\mathrm{pH}$ was determined in distilled water and $1.0 \mathrm{~N} \mathrm{KCl}$ solution using a soil solution ratio of 1:2 (McLean, 1982). Organic carbon was determined by the Walkley - Black wet oxidation method (Allison, 1965). Exchangeable basic cations were extracted with neutral normal ammonium acetate with potassium (K) and sodium (Na) determined by flame photometry and calcium (Ca) and magnesium (Mg) by EDTA titrations (Juo, 1979). Exchangeable acidity was determined titrimetrically using $1.0 \mathrm{~N} \mathrm{KCl}$ extract (McLean, 1982).Available $P$ was determined by the Bray $P$ 1 method (Bray and Kurtz, 1945).Total P was determined by $\mathrm{HCLO}_{4}$ digestion (Jackson, 1958) and organic $\mathrm{P}$ was estimated according to Bray and Kurtz (1945) procedure. Inorganic P was fractionated by the method of Chang and Jackson (1957).

The relationships between the forms of $\mathrm{P}$ and some of the soil properties were established using simple correlations.

\section{RESULTS AND DISCUSSION}

The physical and chemical characteristics of the soils of the study are presented in Table 1.The soils were slightly acidic with $\mathrm{pH}$ values ranging from 5.7 to 6.9 . The particle size distribution shows that the texture of the soil ranged from sandy loam in the topsoil to sandy clay loam in most of the sub-surface horizons. Although the organic carbon content of the soils was generally low, the accumulation decreases with increase in depth in all the profile pits. Jones and Wild(1975) reported low to medium rate of organic carbon accumulation for savanna soils which was attributed to paucity of vegetation cover, rapid mineralization of organic matter, inadequate return of crop residues, bush burning and short fallow periods. Exchangeable bases were in the order, $\mathrm{Ca}>\mathrm{Mg}>\mathrm{K}>\mathrm{Na}$.

Table 1 : Some physical and chemical properties of the soils studied.

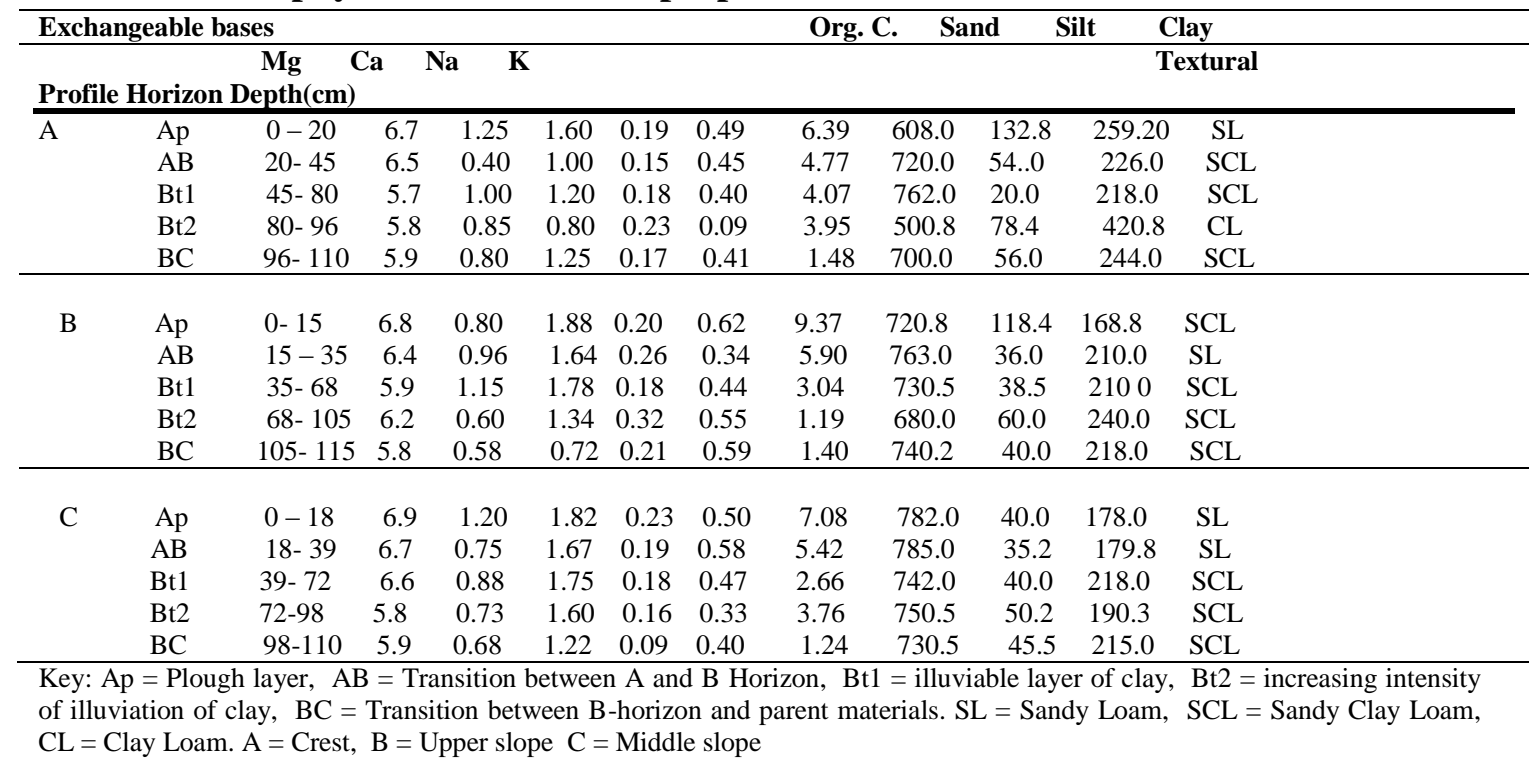


Total Phosphorus: As shown in Table 2, the total P content in all the profiles varied from 102 to $422 \mu \mathrm{g}$ $\mathrm{g}^{-1}$ with a mean of $236.95 \mu \mathrm{g} \mathrm{g}^{-1}$. These values are comparable to the values reported by Adeleye and Omueti (2006) for some soils derived from basement complex parent material. Total $\mathrm{P}$ was generally highest in the upper slope and lowest at lower slope. Also, total $\mathrm{P}$ was highest in the topsoils. This trend could be due to accumulation of litters on the topsoil as also suggested by Osodeke and Osondu (2006).

Organic Phosphorus: The organic P was generally low in all the soil series and the values obtained varied from 21 to $132 \mu \mathrm{g} \mathrm{g}^{-1}$. (Table 2 ) with a mean of $55.8 \mu \mathrm{g} \mathrm{g}^{-1}$. There was appreciable similarity in the organic $\mathrm{P}$ distribution among these soil series. Although the values tended to vary according to organic matter content of the soil, organic $P$ decreased with depth in all the soil profiles. Correlation analysis showed that there was a significant and positive relationship between organic $\mathrm{P}$ with organic carbon $(\mathrm{r}=0.52 *)$ and between organic $\mathrm{P}$ and clay content of the soil $\left(\mathrm{r}=0.56^{*}\right)$. This significant correlation indicates that organic matter influences the levels of organic $\mathrm{P}$ in the soils. Similar trend was reported by Agboola and Oko (1979) in savanna soils of Nigeria.

Available Phosphorus: Available $\mathrm{P}$ varied from 0.4 to $5.54 \mu \mathrm{g} \mathrm{g}^{-1}$ (Table 2) with a mean of $\left(2.47 \mu \mathrm{g} \mathrm{g}^{-}\right.$ $\left.{ }^{1}\right)$. These values are comparable to the values reported by Osodoke and Osondu (2006). They also confirm the report of Aune and Lal (1997) that most Nigerian soils have the available $P$ less than the critical level of $8 \mu \mathrm{g} \mathrm{g} \mathrm{g}^{-1}$ for the humid tropics. Phosphorus distribution down the profiles did not indicate any particular trend. But topsoils generally had the highest values in most of the profiles.
Available $\mathrm{P}$ was highest in crest and topsoil and lowest in the middle slope.

\section{Inorganic Phosphorus fractions}

The various inorganic $\mathrm{P}$ (active $\mathrm{P}$ forms) are shown in Table 2. Fe $-\mathrm{P}$ varied from 19 to $95 \mu \mathrm{g} \mathrm{g}^{-1}$ with a mean of $50.7 \mu \mathrm{g} \mathrm{g}^{-1}, \mathrm{Al}-\mathrm{P}$ varied from 1.75 to $22 \mu \mathrm{g}$ $\mathrm{g}^{-1}$ with a mean of $10.96 \mu \mathrm{g} \mathrm{g}^{-1}$ while $\mathrm{Ca}-\mathrm{P}$ varied from 1.12 to $4.3 \mu \mathrm{g} \mathrm{g}^{-1}$ with a mean value of $2.47 \mu \mathrm{g}$ $\mathrm{g}^{-1}$. Ca $-\mathrm{P}$ had the least value among the active $\mathrm{P}$ forms. This could probably be due to the acidity nature of the soils and the fact that it is the most soluble of the inorganic forms and tends to revert to the less soluble iron and aluminium phosphate in acid soils as suggested by Aghimien et al. (1988). Fe $-\mathrm{P}$ is the least soluble of the inorganic $\mathrm{P}$ fraction and tends to accumulate at the expense of the more soluble $\mathrm{Ca}-\mathrm{P}$ and $\mathrm{Al}-\mathrm{P}$ and this accounted for the relatively higher content of iron phosphate in the acidic soils (Agbimien et al, 1988) and in the order of inactive $\mathrm{P}>\mathrm{Fe}-\mathrm{P}>\mathrm{Al}-\mathrm{P}>\mathrm{Ca}-\mathrm{P}$. Similar order has been reported by several authors (Ibia and Udo, 1993; Adeleye and Omueti, 2006).

Mokwunye and Bationo (2002) also reported that the main sources of plant available $\mathrm{P}$ in soils are generally accepted as active $\mathrm{P}$ form rather than inactive $\mathrm{P}$ form. And secondary Phosphate as Al-P, $\mathrm{Fe}-\mathrm{P}$ and $\mathrm{Ca}-\mathrm{P}$ increase in content with strengthening of weathering and pedogenesis in the soil. Lambers et al (2008) suggested that relationship exist between $\mathrm{P}$ content and forms in soils and stages of soil development. All soil $\mathrm{P}$ is in the primary mineral form (mainly $\mathrm{Al}-\mathrm{P}$ and $\mathrm{Ca}-\mathrm{P}$ mineral) at the beginning of soil development. With time, these inorganic $\mathrm{P}$ weather giving rise to $\mathrm{P}$ in various other forms mainly organic $\mathrm{P}$ (reservoir) occluded $\mathrm{P}$ and available $\mathrm{P}$.

Table 2: Forms of phosphorus in the soils ( $\mathrm{mg} \mathrm{Kg}^{-1}$ )

\begin{tabular}{|c|c|c|c|c|c|c|c|}
\hline Profile & Horizon & Total -P & Organic -P & Fe -P & Al-P & Ca-P & Avail.P (Bray - 1) \\
\hline \multirow[t]{5}{*}{ A } & Ap & 312 & 95 & 42.0 & 1.75 & 2.30 & 5.54 \\
\hline & $\mathrm{AB}$ & 325 & 64 & 33.5 & 2.00 & 1.17 & 5.32 \\
\hline & Bt1 & 223 & 38 & 60.5 & 3.25 & 2.50 & 3.21 \\
\hline & $\mathrm{Bt} 2$ & 257 & 32 & 63.0 & 22.00 & 4.30 & 2.12 \\
\hline & $\mathrm{BC}$ & 105 & 23 & 44.0 & 14.50 & 3.50 & 2.54 \\
\hline \multirow[t]{5}{*}{ B } & Ap & 422 & 132 & 20.5 & 16.25 & 3.20 & 4.22 \\
\hline & $\mathrm{AB}$ & 381 & 94 & 19.0 & 12.00 & 1.90 & 5.34 \\
\hline & Bt1 & 377 & 53 & 32.0 & 13.75 & 1.17 & 0.40 \\
\hline & $\mathrm{Bt} 2$ & 241 & 22 & 76.0 & 6.25 & 2.41 & 1.32 \\
\hline & $\mathrm{BC}$ & 143 & 19 & 88.0 & 19.5 & 2.41 & 0.79 \\
\hline \multirow[t]{5}{*}{$\mathrm{C}$} & Ap & 213 & 80 & 32.0 & 10.25 & 3.10 & 2.67 \\
\hline & $\mathrm{AB}$ & 231 & 45 & 16.5 & 14.75 & 2.70 & 2.69 \\
\hline & Bt1 & 157 & 38 & 50.5 & 2.50 & 1.12 & 1.02 \\
\hline & $\mathrm{Bt} 2$ & 154 & 31 & 49.0 & 17.25 & 3.40 & 1.22 \\
\hline & $\mathrm{BC}$ & 137 & 34 & 90.5 & 9.75 & 4.10 & 0.61 \\
\hline \multirow[t]{5}{*}{ D } & Ap & 305 & 89 & 33.0 & 12.5 & 2.31 & 3.51 \\
\hline & $\mathrm{AB}$ & 224 & 81 & 26.5 & 7.50 & 1.87 & 2.97 \\
\hline & Bt1 & 221 & 78 & 68.0 & 16.0 & 2.36 & 1.64 \\
\hline & $\mathrm{Bt} 2$ & 209 & 47 & 95.5 & 11.0 & 4.21 & 0.88 \\
\hline & $\mathrm{BC}$ & 102 & 21 & 74.0 & 6.50 & 2.44 & 1.30 \\
\hline
\end{tabular}


Table 3. Correlation coefficient between soil $P$ and some soil properties

\begin{tabular}{|c|c|c|c|c|c|c|}
\hline & Total - P & Organic $-\mathrm{P}$ & $\mathrm{Fe}-\mathrm{P}$ & $\mathrm{Al}-\mathrm{P}$ & $\mathrm{Ca}-\mathrm{P}$ & Available $-\mathrm{P}$ \\
\hline $\mathrm{pH}$ & 0.16 & 0.05 & 0.09 & -0.09 & -0.19 & 0.25 \\
\hline Sand & 0.23 & $-0.49 *$ & -0.21 & $0.45^{*}$ & -0.16 & -0.33 \\
\hline Silt & -0.31 & 0.23 & -0.27 & -0.26 & -0.22 & -0.16 \\
\hline Clay & 0.23 & $0.56^{*}$ & 0.34 & -0.33 & 0.26 & $0.43 *$ \\
\hline Org. C & -.014 & $0.52 *$ & -0.25 & 0.21 & -0.14 & $0.52 *$ \\
\hline $\mathrm{K}$ & -0.12 & -0.32 & -0.22 & 0.07 & -0.15 & 0.28 \\
\hline $\mathrm{Mg}$ & -0.27 & 0.26 & $0.51 *$ & 0.05 & 0.24 & 0.19 \\
\hline
\end{tabular}

\section{CONCLUSION}

In conclusion, this study has shown that the distribution of $\mathrm{P}$ along a toposequence varies with topographic units. Also, the $\mathrm{P}$ status of the Savanna soils is low and organic matter is found to be influencing available P. Since organic matter content of the surface soil determines the $\mathrm{P}$ content of the soil, the surface layer should be protected against natural disasters for effective fertility maintenance especially with regard to $\mathrm{P}$.

\section{REFERENCES}

Adeleye, E.O. and J.A.I. Omueti. (2006). Profile distribution of phosphorus fractions in soils derived from basement complex rocks in south western Nigerian. Nig. J. Soil Sci.,16: $52-58$.

Aghimien, E A., E.J. Udo and O. Ataga. (1988). Profile distribution of forms of Iron and Aluminium in the hydromorphic soils of southeastern Nigeria. J. West African Sci. Association, 31: 57 - 70.

Agboola, A.A. and B. Oko. (1976). An attempt to evaluate plant available $\mathrm{P}$ in Western Nigerian soils under shifting cultivation. Agron.J.,68: 798 - 801.

Ahn, P.M. (1993). Tropical soils and fertilizer use. Longman and Scientific Technical U.K., pp: 207.

Allison, I. E. (1965). Organic carbon : In C. A. Black (ed). Methods of Soil Analysis. Agron. 9 Amer. Soc. Agron. Madison Wis pp 374 390

Aune, J.B. and R. Lal. (1997). Agricultural productivity in the tropics and critical limits of properties of oxisols, ultisols and alfisols. Trop. Agric. (Trinidad), 74: 96 - 103.

Bray, R.H. and L.T. Kurtz. (1945). Determination of total, organic and available forms of phosphorus in soils. Soil Sci., 59; $39-45$.

Chang, S.C. and M.L. Jackson. (1957). Fractionation of soil phosphorus. Soil Sci., 84: 133 - 144.

Ibia, T.O. and E.J. Udo, 1993. Phosphorus forms and fixation of representative soils of Akwa Ibom State of Nigeria. Geoderma, 58: 95 106.

IITA. (1976). Selected methods for soil and plant analysis. IITA, Ibadan - Nigeria. Manual series No 1. pp 70
Jackson, M.L. (1958). Soil chemical analysis.Prentice Hall. NewYork, pp: 498.

Jones, M.J. and A.Wild. (1975). Soil of West Africa Savanna. Commonwealth Agricultural Bureaux, Harpenden.U.K. pp.24

Jianbo, S., L. Yuan, J. Zhang, Y. Li, Z. Bai, X. Chen, W. Zhang and F. Zhan. (2011). Phosphorus dynamics : from soil to plant. Plant Physiology. 156: 997- 1005

Juo, A. S. R. (1979). Selected method of soil and plant analysis. IITA manual series No. 2

Juo, A.S.R. and F.R. Moorman. (1981). Characteristics of two soil toposequences in southeastern Nigeria and their relation to potential agricultural land use. Nig. J. Soil Sci., 1: $47-61$

Lambers, H., J. A. Raven, G. R. Shaver and S. E. Smith. (2008). Plant nutrient-acquisition strategies changes with soil age. Trends Ecol. Evolution. 23(2), 95 - 103

McLean, E.O. (1982). Soil pH and lime requirement. In: A. L. Page et. al. (eds), Methods of soil analyses (No. 9, part 2), 199 - 224. Amer. Soc. of Agron,; Soil Sci. Soc. Am; Inc. Madison, Wisconsin, U.S.A.

Mokwunye, U. and A. Bationo. (2002). Meeting the phosphorus needs of the soils and crops of West Africa : the role ingenious phosphate rocks. In :Vandalauwe et al (Eds) Integrated Plant Nutrient Management in Sub - Sahara Africa Cabi Publishing, USA., pp:352

Ogban, P.I., O. Babalola and A.M. Okoji. (1999). Profile characteristics of a typical toposequence in southern Nigeria. African Soils, 28: $147-165$.

Oluwatosin, G.A., J.O. Ojo-Atere, O. Osiname and J.A. Audcharan. (2001). Influence of topographic position on crop response to a different ration of fertilizers in southwestern Nigeria. Moor Plantation J. Agric. Res., 2: 1 -7 .

Osodeke, V.E. and N.E. Osondu. (2006). Phosphorus distribution along a toposequence of coastal plain sand parent material in southeastern Nigeria. Agric. J., 1(3): 167 - 171. 